\title{
Possible anti-diabetic potentials of Annona muricata (soursop): inhibition of a-amylase and a-glucosidase activities
}

Kinsgley Chukwunonso Agu', Nkeiruka Eluehike ${ }^{1 *}$ D, Reuben Oseikhumen Ofeimun ${ }^{1}$, Deborah Abile², Godwin Ideho', Marianna Olukemi Ogedengbe ${ }^{1}$, Priscilla Omozokpea Onose ${ }^{1}$ and Olusola Olalekan Elekofehinti ${ }^{3}$

\begin{abstract}
Background: Annona muricata has been used in folklore in the management of diabetes. A major strategy in decreasing postprandial hyperglycemia in diabetes involves the inhibition of carbohydrate-hydrolyzing enzymes - aamylase and a-glucosidase. Thus, this study evaluated the in vivo and in vitro inhibitory potentials of the different parts (fruit-pulp, leaf, stem-bark and root-bark) of Annona muricata.

Methods: A total of 120 Wistar rats were treated with methanol extracts for 28 days after which blood and tissue samples were collected for a-amylase assay. In vitro inhibitory properties of methanol, ethyl acetate and dichloromethane extracts of the various parts of the plant on a-amylase and a-glucosidase activities were performed using standard procedures. The mode and mechanism of interactions between the enzymes and extracts (and isolated acetogenin) were determined using various kinetic interpolations and in silico experiments.

Result: The fruit-pulp and root-bark methanolic extracts better -inhibited plasma and tissue amylase in vivo. The in vitro studies revealed that the stem-bark methanolic, fruit-pulp ethyl acetate, and leaf dichloromethane extracts, better inhibited a-amylase activity compared with the standard acarbose. Also, the leaf methanol, fruit-pulp ethyl acetate, and root-bark dichloromethane extract better inhibited a-glucosidase activity. These observations were corroborated with their higher Bmax and Vmax and lower Kd values. All the extracts exhibited an "uncompetitive" type of inhibition pattern. Also, the isolated acetogenin (15-acetyl guanacone) from the fruit-pulp showed a better binding affinity compared to the standard drug, Metformin.
\end{abstract}

Conclusion: Better natural remedy for diabetics can be obtained from Annona muricata with minimal or no adverse side effects.

Keywords: Annona muricata, a-Amylase, a-Glucosidase, Acarbose, Metformin

\section{Introduction}

Diabetes mellitus is a chronic endocrine disorder of carbohydrate, fat and protein metabolism characterized by an increase in both fasting and postprandial glucose level and it has been reported to be the major cause of mortality worldwide. There is an alarming projection of 471 million people with the disease by the year 2035 [1]. Diabetes is grouped into two forms; type 1, insulin dependent diabetes mellitus and type 2, non- insulin

\footnotetext{
* Correspondence: nkeiruka.ezeugwu@uniben.edu

'Department of Medical Biochemistry, School of Basic Medical Sciences,

University of Benin, Benin City, Edo State 300001, Nigeria

Full list of author information is available at the end of the article
}

dependent diabetes mellitus. Type 2 is the major form accounting about $90 \%$ of cases worldwide [2]. In type 2 diabetes mellitus (DM2), postprandial hyperglycemia is important in the development of the disease; Current treatment for Type 2 diabetes remains inadequate so prevention is preferable [3]. The major strategy for the management of Type 2 diabetes is to decrease postprandial hyperglycemia. The $\alpha$-glucosidase inhibitors, such as acarbose, have been used in the clinic to control blood glucose increase, especially postprandial, in DM2 [4].

Herbal medicine is predominantly available for the treatment of diabetes and the main advantages of the use of herbal drugs are effectiveness, safety, and 
acceptability [5]. The mechanism of action of these medicinal plant of its products involve retarding the absorption of glucose by inhibiting the carbohydrate hydrolyzing enzymes, such as pancreatic amylase and $\alpha-$ glucosidase and through the inhibition of these enzymes, medicinal plants can effectively control the postprandial rise in blood glucose. Several medicinal plants have a high potential in inhibiting $\alpha$-amylase enzyme activity [6].

Annona muricata (A. muricata) is a tropical plant species belonging to family Annonaceae and known for its many ethnomedicinal uses. All parts of Annona are used in natural medicine in the tropics. It is considered to be a good source of natural antioxidants for various diseases. Traditionally, the leaves are used for headaches, insomnia, cystitis, liver problems, and diabetes, antitumor, anti-inflammatory. The health benefits of this plant have been attributed to their unique phytochemical composition [7-10].

There is, however, a paucity of information that demonstrates the comparative $\alpha$-amylase and $\alpha$-glucosidase inhibitory properties of different extracts and fractions, of the various parts of the plant (fruit-pulp, leaf, stembark and root-bark) with relation to its anti-diabetic activity. Hence, the present study was carried out to investigate the comparative $\alpha$-amylase and $\alpha$-glucosidase inhibitory potentials of methanolic, ethyl acetate and dichloromethane extracts of the fruit-pulp, leaf, stem-bark and root-bark of Annona muricata and also to determine the possible modes and mechanisms of inhibition of these enzymes by these extracts. The justification for this research is the severe gastrointestinal side effects such as abdominal pain, flatulence and diarrhea that have been reported in the patients after the use of conventional drugs $[11,12]$, so that the identification of natural interventions through the use of plants like Annona muricata, becomes beneficial due to their very minimal or absence of negative side effects.

\section{Materials and method}

\section{Collection of plant materials and preparation of extracts}

Fresh parts of the plant which includes the fruit-pulp, leaf, stem-bark, and root-bark were collected from household gardens around the University of Benin, Edo state, Nigeria. The plant was identified by Dr. Bamidele of the Department of Plant Biology and Biotechnology, University of Benin, and authenticated by Professor Mc Idu of the same department. A voucher specimen number, UBHa 0205, was deposited at the Herbarium of Department of Plant Biology and Biotechnology, University of Benin. The properly washed plant samples were pulverized after drying at room temperature (about $25^{\circ} \mathrm{C}$ ). The pulverized plant parts were extracted by macerating $500 \mathrm{~g}$ of each part in methanolic, ethyl acetate and dichloromethane for $72 \mathrm{~h}$ after which they were filtered with a muslin cloth and the filtrate was concentrated to dryness using a rotary evaporator. The concentrated extracts were stored in an airtight container (percentage yields of methanolic, $46.30 \%$, ethyl acetate, $31.83 \%$ and dichloromethane, 29.44\%) and kept in the freezer at $4{ }^{\circ} \mathrm{C}$ until use.

\section{In vivo studies using methanolic extracts of the various parts of Annona muricata}

A total of 120 male albino Wistar rats weighing $190 \mathrm{~g}-$ $220 \mathrm{~g}$ were bought and kept in galvanized cages in the Department of Biochemistry animal house. They were divided into six groups containing 5 rats each. They were allowed access to feed and water ad libitum on a $12 \mathrm{~h}$ light / $12 \mathrm{~h}$ dark cycle. The animals were acclimatized for 2 weeks before the commencement of the administration of the extract. Approval of the research ethics committee on guidelines and principles for the handling of animals, College of Medical Sciences, University of Benin (CMR/REC/2014/57) was adopted and strictly adhered to. The design for the administration of methanolic extracts of various parts of the plants is shown below:

\begin{tabular}{lllll}
\hline $\begin{array}{l}\text { Doses administered (mg/ } \\
\text { kg b.w.) }\end{array}$ & $\begin{array}{l}\text { Extract } \\
\text { Fruits }\end{array}$ & $\begin{array}{l}\text { administered } \\
\text { Leaf }\end{array}$ & $\begin{array}{l}\text { Stem- } \\
\text { bark }\end{array}$ & $\begin{array}{l}\text { Root- } \\
\text { bark }\end{array}$ \\
0(control) & 5 rats & 5 rats & 5 rats & 5 rats \\
100 & 5 rats & 5 rats & 5 rats & 5 rats \\
200 & 5 rats & 5 rats & 5 rats & 5 rats \\
400 & 5 rats & 5 rats & 5 rats & 5 rats \\
600 & 5 rats & 5 rats & 5 rats & 5 rats \\
800 & 5 rats & 5 rats & 5 rats & 5 rats \\
\hline
\end{tabular}

\section{Administration of extracts}

The extracts were administered daily with the aid of an orogastric tube. Care was taken not to inflict injuries to the rats.

\section{Biochemical assay}

At the end of the 28-day experimental period, the animals fasted overnight and blood samples were collected into plain sample bottles and allowed to clot for $30 \mathrm{~min}$ after which it was centrifuged at $3000 \mathrm{rpm}$ for $15 \mathrm{~min}$. The serum was collected separately and used for serum amylase assay. Serum amylase activity was measured using the method of Wallenfels et al. [13]. Pancreatic tissues were also excised and homogenized in ice-cold normal saline $(1: 4 \mathrm{w} / \mathrm{v})$, centrifuged at $1000 \mathrm{~g}$ for $15 \mathrm{~min}$ and the supernatant was used for tissue pancreatic amylase assay. 
Table 1 Dose-response characteristics of the influence of Annona muricata methanolic extracts on plasma amylase activity

\begin{tabular}{|c|c|c|c|c|c|c|c|c|c|c|}
\hline & \multicolumn{2}{|c|}{$\begin{array}{l}\text { Dose-Response } \\
\text { characteristics }\end{array}$} & \multicolumn{2}{|c|}{$\begin{array}{l}\text { Sigmoid plot interpolation } \\
\text { characteristics }\end{array}$} & \multicolumn{2}{|c|}{$\begin{array}{l}\text { Hyperbola plot } \\
\text { interpolation } \\
\text { characteristics }\end{array}$} & \multicolumn{2}{|c|}{$\begin{array}{l}\text { Michaelis-Menten's } \\
\text { kinetics }\end{array}$} & \multicolumn{2}{|c|}{$\begin{array}{l}\text { Straight line regression } \\
\text { interpolation characteristics }\end{array}$} \\
\hline & LogIC50 & IC50 & $\overline{R^{2}}$ & Hill's slope & Bmax & $K d$ & $\mathrm{Km}$ & $V \max$ & Y-intercept & slope \\
\hline Fruit-pulp & 1.606 & 40.36 & 0.002 & 0.064 & 0.712 & -0.009 & $2.15 \times 10^{-10}$ & 0.71 & 0.70 & 0.005 \\
\hline Leaf & 2.409 & 256.60 & 0.796 & -1.274 & 0.242 & -1.446 & $1.55 \times 10^{-16}$ & 0.61 & 1.92 & -0.519 \\
\hline Stem-bark & 2.478 & 300.50 & 0.888 & -1.674 & 0.226 & -1.486 & $1.71 \times 10^{-16}$ & 0.59 & 2.01 & -0.562 \\
\hline Root-bark & 2.687 & 486.20 & 0.267 & 0.963 & 0.847 & 0.656 & 0.66 & 0.85 & 0.53 & 0.056 \\
\hline
\end{tabular}

$B m a x=$ maximum binding capacity $(\mathrm{U} / \mathrm{L}), K d=$ dissociation constant $(\mathrm{mg} / \mathrm{dL}), K m=$ Michaelis-Menten's constant $(\mathrm{mg} / \mathrm{dL})$ and $\mathrm{Vmax}=\mathrm{maximum}$ velocity $(\mathrm{U} / \mathrm{L})$

In vitro studies using extracts of the various parts of Annona muricata

\section{a- amylase inhibition assay}

Serial dilutions of the plant extracts between 0 to $200 \mu \mathrm{L}$ were prepared by mixing with $500 \mu \mathrm{L}$ Sodium phosphate buffer $\left(0.02 \mathrm{~mol} / \mathrm{dm}^{3}\right.$, at $\mathrm{pH}=6.9$ and $0.006 \mathrm{NaCl}$ as the stabilizer), containing pancreatic alpha-amylase $(0.50$ $\mathrm{mg} / \mathrm{mL}$ ) of Porcine origin (EC 3.2.1.1). The mixtures were incubated at $37^{\circ} \mathrm{C}$ for $5 \mathrm{~min}$, and then $500 \mu \mathrm{L}$ of starch solution $\left(1 \mathrm{mg} / 100 \mathrm{~mL}\right.$ in $0.02 \mathrm{~mol} / \mathrm{dm}^{3}$ sodium buffer at $\mathrm{pH}$ of 6.9 with $0.006 \mathrm{NaCl}$ ) was introduced into the reaction mixtures. The reaction mixtures were subsequently, incubated at $37 \mathrm{oC}$ for $5 \mathrm{~min}$ in a water bath. The reaction was then stopped using $1.0 \mathrm{~mL}$ dinitrosalicylic acid (DNSA) and further incubated in boiling water for $5 \mathrm{~min}$. The blank sample had no starch solution and enzyme in it, while the control (reference sample) had all the reagents and the enzyme except the starch solution. Acarbose served as positive control. When the reaction mixtures were cool, absorbance was read at $540 \mathrm{~nm}[14,15]$.

$$
\begin{aligned}
& \text { Percentage } \alpha \text {-amylase inhibition }(\%) \\
& =\frac{\text { Aref }- \text { Asample }}{\text { Aref }} \times 100
\end{aligned}
$$

\section{a - glucosidase inhibition assay}

Serial dilutions of the plant extracts between 0 to $200 \mu \mathrm{L}$ were prepared by mixing with $100 \mu \mathrm{L}$ Sodium phosphate buffer $\left(0.1 \mathrm{~mol} / \mathrm{dm}^{3}\right.$, at $\left.\mathrm{pH}=6.9\right)$ containing alphaglucosidase (EC 3.2.1.2; 1.0 U/mL) and then incubating at $37^{\circ} \mathrm{C}$ for $5 \mathrm{~min} .0 .05 \mathrm{~mL}$ of para-nitrophenyl- $\alpha$-D-glucopyranoside $\left(5.0 \mathrm{mmole} / \mathrm{dm}^{3}\right)$ solution in Sodium phosphate buffer $\left(0.1 \mathrm{~mol} / \mathrm{dm}^{3}\right.$, at $\left.\mathrm{pH}=6.9\right)$ was added to the reaction mixture and incubated at $37^{\circ} \mathrm{C}$ for $5 \mathrm{~min}$. The reaction was then stopped using $1.0 \mathrm{~mL}$ dinitrosalicylic acid (DNSA) and further incubated in boiling water for $5 \mathrm{~min}$. The reaction mixtures were allowed to cool and then absorbance read at $405 \mathrm{~nm}$ [16]. The blank sample had no starch solution and enzyme in it, while the control (reference sample) had all the reagents and the enzyme except the starch solution. Acarbose served as the positive control.

$$
\begin{aligned}
& \text { Percentage } \alpha \text {-glucosidase inhibition }(\%) \\
& =\frac{\text { Aref-Asample }}{\text { Aref }} \times 100 .
\end{aligned}
$$

\section{Investigation of inhibitory concentrations (IC50), modes and mechanisms of inhibition of a-amylase and $a$ - glucosidase activity (enzyme kinetics)}

The mode and mechanisms of interactions between the enzymes and extracts (as well as, isolated compound) were studied using the various kinetic interpolations, viz., sigmoid (Hill's slope), a hyperbola (maximum binding capacity, Bmax, and dissociation constant, $K d$ ), and Michaelis-Menten's ( $K m$ and $V \max$ ). These were used to determine the IC50 of the extracts. The Bmax and $K d$ demonstrated the degree of binding and period of inhibition, which gave an idea of the level of efficacy

\begin{tabular}{|c|c|c|c|c|c|c|c|c|c|c|}
\hline & \multicolumn{2}{|c|}{$\begin{array}{l}\text { Dose-Response } \\
\text { characteristics }\end{array}$} & \multicolumn{2}{|c|}{$\begin{array}{l}\text { Sigmoid plot interpolation } \\
\text { characteristics }\end{array}$} & \multicolumn{2}{|c|}{$\begin{array}{l}\text { Hyperbola plot } \\
\text { interpolation } \\
\text { characteristics }\end{array}$} & \multicolumn{2}{|c|}{$\begin{array}{l}\text { Michaelis-Menten's } \\
\text { kinetics }\end{array}$} & \multicolumn{2}{|c|}{$\begin{array}{l}\text { Straight line regression } \\
\text { interpolation characteristics }\end{array}$} \\
\hline & LogIC50 & IC50 & $\overline{R^{2}}$ & Hill's slope & $\overline{B m a x}$ & $K d$ & $\mathrm{Km}$ & Vmax & Y-intercept & slope \\
\hline Fruit-pulp & 3.726 & 532.00 & 0.000 & 0.029 & 0.673 & -1.11 & $4.25 \times 10^{-11}$ & 48.00 & 43.89 & 1.634 \\
\hline Leaf & 2.469 & 294.60 & 0.826 & -1.467 & 0.496 & -43.06 & $2.16 \times 10^{-16}$ & 44.41 & 232.70 & -74.80 \\
\hline Stem-bark & 2.462 & 289.70 & 0.784 & -1.344 & 0.489 & -41.62 & $1.64 \times 10^{-16}$ & 44.48 & 221.70 & -70.41 \\
\hline Root-bark & 2.756 & 569.80 & 0.702 & -49.47 & 0.721 & 10.57 & $9.77 \times 10^{-19}$ & $2.07 \times 10^{21}$ & -117.40 & 67.06 \\
\hline
\end{tabular}
of the extracts. The IC50 gave an idea of the level of potency of the extracts in inhibiting the enzymes.

Table 2 Dose-enzyme response characteristics of the influence of Annona muricata methanolic extracts on tissue amylase activity

$B m a x=$ maximum binding capacity $(\mathrm{U} / \mathrm{L}), K d=$ dissociation constant $(\mathrm{mg} / \mathrm{dL}), K m=$ Michaelis-Menten's constant $(\mathrm{mg} / \mathrm{dL})$ and $\mathrm{Vmax}=\mathrm{maximum}$ velocity $(\mathrm{U} / \mathrm{L})$ 
Table 3 Dose-response characteristics of the influence of Annona muricata methanolic extracts on a-amylase activity

\begin{tabular}{|c|c|c|c|c|c|c|c|c|c|c|}
\hline & \multicolumn{2}{|c|}{$\begin{array}{l}\text { Dose-Response } \\
\text { characteristics }\end{array}$} & \multicolumn{2}{|c|}{$\begin{array}{l}\text { Sigmoid plot interpolation } \\
\text { characteristics }\end{array}$} & \multicolumn{2}{|c|}{$\begin{array}{l}\text { Hyperbola plot } \\
\text { interpolation } \\
\text { characteristics }\end{array}$} & \multicolumn{2}{|c|}{$\begin{array}{l}\text { Michaelis-Menten's } \\
\text { kinetics }\end{array}$} & \multicolumn{2}{|c|}{$\begin{array}{l}\text { Straight line regression } \\
\text { interpolation characteristics }\end{array}$} \\
\hline & LoglC50 & IC50 & $\overline{R^{2}}$ & Hill's slope & Bmax & $K d$ & $\mathrm{Km}$ & $V \max$ & Y-intercept & slope \\
\hline Fruit-pulp & 0.335 & 2.163 & 0.927 & 5.029 & 40.67 & -0.038 & $1.603 \times 10^{-16}$ & 44.37 & 34.14 & 24.40 \\
\hline Leaf & 0.266 & 1.846 & 0.966 & 4.832 & 46.41 & -0.049 & $1.211 \times 10^{-16}$ & 52.17 & 52.02 & 27.95 \\
\hline Stem-bark & 0.265 & 1.843 & 0.983 & 4.447 & 45.83 & -0.052 & $1.212 \times 10^{-16}$ & 51.89 & 52.32 & 29.08 \\
\hline Root-bark & 0.338 & 2.177 & 0.947 & 5.077 & 40.46 & -0.037 & $1.264 \times 10^{-16}$ & 44.08 & 37.93 & 24.22 \\
\hline Acarbose & 0.236 & 1.722 & 0.996 & 3.695 & 51.17 & -0.079 & $2.220 \times 10^{-16}$ & 63.17 & 65.59 & 41.67 \\
\hline
\end{tabular}

$B m a x=$ maximum binding capacity $(\mathrm{U} / \mathrm{L}), K d=$ dissociation constant $(\mathrm{mg} / \mathrm{dL}), K m=$ Michaelis-Menten's constant $(\mathrm{mg} / \mathrm{dL})$ and $V m a x=$ maximum velocity $(\mathrm{U} / \mathrm{L})$

\section{In silico experiments}

The acetogenin, 15-acetyl guanacone, which has previously been isolated from the leaf ethyl acetate extract and characterized by Agu et al. [8], was subjected to molecular docking analyses obtaining their binding affinities (Ba), in an attempt to determine whether the influence of the extracts originated from this compound as the mechanistic molecule. This was compared against a standard anti-diabetic drug, metformin.

\section{Protein preparation and generation of 3-D structure using homology modeling}

The starting structure (PDB ID: 4GL7) required for docking was retrieved from the protein data bank repository (HTTP: //www.rcsb.org). Prior to docking, water and ligand coordinates were deleted. $\alpha$-Amylase and $\alpha$-glucosidase were downloaded from www.pubmed. org and used to model the starting structure of the elucidated compound used in the current study. Homology modeling was done on Swiss Model Server (http://swissmodel.expasy.org). This requires one sequence of a known 3D structure with significant similarity with the target sequence. The coordinate file of template from protein data bank (PDB ID: 4GL7) was used to model the 3D structure of VEGF2.

\section{Ligand preparation for docking}

The 3D structure of the elucidated compound was built using Marvin-sketch and optimized for docking studies. The optimized ligand molecules (the compound) was docked into a refined aromatase model using "LigandFit" in the Auto-Dock 4.2.

\section{Molecular docking calculations}

These were carried out through BSP-SLIM and Autodock. The modeled structures of VEGF2 and the elucidated compound was loaded on BSP-SLIM server and Auto-dock/Vina and all the water molecules were removed prior to the upload. BSP-SLIM is known as a blind docking method, which primarily uses the structural template match to identify putative ligand binding sites, followed by fine-tuning and ranking of ligand conformations in the binding sites through the SLIM-based shape and chemical feature comparisons [17]. Protein snapshots were taken and analyzed using PYMOL.

\section{Statistical analysis}

The data were entered into Microsoft Excel v.13, prior to analysis. The Graph Pad Prism Software, inc., (version $6.01,2012$ ) was used to analyze to obtain the means, SEM and IC50, using the data using the One-way

Table 4 Dose-response characteristics of the influence of Annona muricata ethyl acetate extracts on a-amylase activity

\begin{tabular}{|c|c|c|c|c|c|c|c|c|c|c|}
\hline & \multicolumn{2}{|c|}{$\begin{array}{l}\text { Dose-Response } \\
\text { characteristics }\end{array}$} & \multicolumn{2}{|c|}{$\begin{array}{l}\text { Sigmoid plot interpolation } \\
\text { characteristics }\end{array}$} & \multicolumn{2}{|c|}{$\begin{array}{l}\text { Hyperbola plot } \\
\text { interpolation } \\
\text { characteristics }\end{array}$} & \multicolumn{2}{|c|}{$\begin{array}{l}\text { Michaelis-Menten's } \\
\text { kinetics }\end{array}$} & \multicolumn{2}{|c|}{$\begin{array}{l}\text { Straight line regression } \\
\text { interpolation characteristics }\end{array}$} \\
\hline & LoglC50 & IC50 & $\overline{R^{2}}$ & Hill's slope & $B$ max & $K d$ & $\overline{K m}$ & $V \max$ & Y-intercept & slope \\
\hline Fruit-pulp & 0.341 & 2.196 & 1.000 & 4.412 & 44.75 & -0.037 & $1.341 \times 10^{-16}$ & 48.68 & 48.77 & 50.30 \\
\hline Leaf & 0.503 & 3.186 & 1.000 & 2.003 & 46.33 & -0.056 & $1.151 \times 10^{-16}$ & 52.99 & 53.09 & 52.56 \\
\hline Stem-bark & 0.644 & 4.409 & 1.000 & 1.892 & 45.13 & -0.052 & $1.704 \times 10^{-16}$ & 51.07 & 51.17 & 51.18 \\
\hline Root-bark & 0.477 & 2.997 & 1.000 & 3.247 & 41.72 & -0.033 & $1.275 \times 10^{-16}$ & 45.00 & 45.08 & 47.18 \\
\hline Acarbose & 0.236 & 1.722 & 1.000 & 1.481 & 51.17 & -0.079 & $2.220 \times 10^{-16}$ & 63.07 & 65.59 & 41.67 \\
\hline
\end{tabular}

Bmax = maximum binding capacity $(\mathrm{U} / \mathrm{L}), K d=$ dissociation constant $(\mathrm{mg} / \mathrm{dL}), K m=$ Michaelis-Menten's constant $(\mathrm{mg} / \mathrm{dL})$ and $V m a x=$ maximum velocity $(\mathrm{U} / \mathrm{L})$ 
Table 5 Dose-response characteristics of the influence of Annona muricata dichloromethane extracts on a-amylase activity

\begin{tabular}{|c|c|c|c|c|c|c|c|c|c|c|}
\hline & \multicolumn{2}{|c|}{$\begin{array}{l}\text { Dose-Response } \\
\text { characteristics }\end{array}$} & \multicolumn{2}{|c|}{$\begin{array}{l}\text { Sigmoid plot interpolation } \\
\text { characteristics }\end{array}$} & \multicolumn{2}{|c|}{$\begin{array}{l}\text { Hyperbola plot } \\
\text { interpolation } \\
\text { characteristics }\end{array}$} & \multicolumn{2}{|c|}{$\begin{array}{l}\text { Michaelis-Menten's } \\
\text { kinetics }\end{array}$} & \multicolumn{2}{|c|}{$\begin{array}{l}\text { Straight line regression } \\
\text { interpolation characteristics }\end{array}$} \\
\hline & LoglC50 & IC50 & $\overline{R^{2}}$ & Hill's slope & $B \max$ & $K d$ & $\mathrm{Km}$ & $V \max$ & Y-intercept & slope \\
\hline Fruit-pulp & 0.441 & 2.761 & 1.000 & 2.294 & 46.18 & -0.054 & $1.182 \times 10^{-16}$ & 52.51 & 52.61 & 52.32 \\
\hline Leaf & 0.328 & 2.127 & 1.000 & 3.863 & 46.06 & -0.044 & $1.259 \times 10^{-16}$ & 51.07 & 51.17 & 51.83 \\
\hline Stem-bark & 0.863 & 7.286 & - & 1.378 & 46.86 & -0.061 & $2.098 \times 10^{-16}$ & 54.32 & 54.42 & 53.26 \\
\hline Root-bark & 0.931 & 8.528 & - & 1.418 & 46.07 & -0.059 & $1.113 \times 10^{-16}$ & 53.22 & 53.32 & 52.48 \\
\hline Acarbose & 0.236 & 1.722 & 1.000 & 1.481 & 51.17 & -0.079 & $2.220 \times 10^{-16}$ & 63.07 & 65.59 & 41.67 \\
\hline
\end{tabular}

$B m a x=$ maximum binding capacity $(\mathrm{U} / \mathrm{L}), K d=$ dissociation constant $(\mathrm{mg} / \mathrm{dL}), K m=$ Michaelis-Menten's constant $(\mathrm{mg} / \mathrm{dL})$ and $V m a x=$ maximum velocity $(\mathrm{U} / \mathrm{L})$

analysis of variance and unpaired sample students' Ttest. The level of significance was taken as $p \leq 0.05$. The sigmoid (Hill's slope), a hyperbola (maximum binding capacity, Bmax, and dissociation constant, $K d$ ), and Michaelis-Menten's ( $K m$ and Vmax) were also determined using the Graph Pad Prism Software.

\section{Results}

In vivo study (Tables 1 and 2 )

\section{In vitro studies (Tables 3, 4, 5, 6, 7 and 8)}

\section{Discussion}

$\alpha$-Amylase catalyzes the hydrolysis of $\alpha-(1,4)-D-$ glycosidic linkages of starch and other glucose polymers. Inhibitors of this enzyme could be of use in the treatment or management of diabetes. In the management of diabetic patients, the inhibition of the enzymes that are involved in the breakdown of carbohydrate e.g., $\alpha$-amylase and $\alpha$-glucosidase, leads to inhibition of starch hydrolysis, thus, resulting in a decreased level of glucose available for assimilation into the blood (regulating postprandial glycemic level) . Several In vitro studies have confirmed the inhibitory potential of medicinal plants on $\alpha$-amylase and $\alpha$-glucosidase activities and in some cases, the bioactive compounds, which presumably are responsible for this mechanism of action, have been identified.
However, studies conducted in animal models are few [18] and even less abundant are the studies performed in human subjects.

\section{In vivo investigations}

In this study, methanol extracts of the different part of Annona muricata (fruit-pulp, leaf, stem-bark, and rootbark) were investigated (In vivo) for their potential inhibitory effects on plasma and pancreatic tissue amylase activities at varying doses of 0 to $800 \mathrm{mg} / \mathrm{kg}$ (Figs. 1 and 2) body weight in male albino Wistar rats. Amongst the parts of the plants tested, the fruit-pulp showed the highest inhibitory effect on plasma and tissue amylase activities. The root-bark showed the second highest inhibitory effect, this was followed by the leaf extract and then the stem-bark extract. As demonstrated in Table 1, the IC50 of the methanol extract of Annona muricata fruit-pulp on plasma amylase $(40.36 \mathrm{mg} / \mathrm{kg})$ gave a better response compared to the other part extracts. However, on the whole, the fruit-pulp and root-bark methanol extract better inhibited the plasma $\alpha$-amylase as represented by their Bmax, $K d$ and Vmax values. Also from Table 2 , the methanol extracts of the fruit-pulp and rootbark demonstrated a better Bmax compared to leaf and stem-bark extracts that demonstrated better IC50 and $K d$. Summarily, the IC50, Kd and Vmax represented how potent the extracts were (i.e., the lower these enzyme kinetic properties, the higher the

Table 6 Dose-response characteristics of the influence of Annona muricata methanol extracts on a-glucosidase activity

\begin{tabular}{|c|c|c|c|c|c|c|c|c|c|c|}
\hline & \multicolumn{2}{|c|}{$\begin{array}{l}\text { Dose-Response } \\
\text { characteristics }\end{array}$} & \multicolumn{2}{|c|}{$\begin{array}{l}\text { Sigmoid plot interpolation } \\
\text { characteristics }\end{array}$} & \multicolumn{2}{|c|}{$\begin{array}{l}\text { Hyperbola plot } \\
\text { interpolation } \\
\text { characteristics }\end{array}$} & \multicolumn{2}{|c|}{$\begin{array}{l}\text { Michaelis-Menten's } \\
\text { kinetics }\end{array}$} & \multicolumn{2}{|c|}{$\begin{array}{l}\text { Straight line regression } \\
\text { interpolation characteristics }\end{array}$} \\
\hline & LoglC50 & IC50 & $\overline{R^{2}}$ & Hill's slope & $B \max$ & $K d$ & $\overline{K m}$ & $V \max$ & Y-intercept & slope \\
\hline Fruit-pulp & 0.828 & 6.734 & 0.000 & 2.726 & 38.83 & -0.030 & $1.176 \times 10^{-16}$ & 41.59 & 41.67 & 44.23 \\
\hline Leaf & 0.210 & 1.623 & 0.987 & 5.105 & 51.49 & -0.063 & $1.825 \times 10^{-16}$ & 60.12 & 60.23 & 58.14 \\
\hline Stem-bark & 0.318 & 2.077 & 1.000 & 2.116 & 49.05 & -0.067 & $1.565 \times 10^{-16}$ & 57.93 & 57.93 & 55.96 \\
\hline Root-bark & 0.812 & 6.483 & 0.000 & 3.002 & 37.76 & -0.030 & $1.759 \times 10^{-16}$ & 40.44 & 40.44 & 43.14 \\
\hline Acarbose & 0.236 & 1.722 & 1.000 & 1.481 & 51.17 & -0.079 & $2.220 \times 10^{-16}$ & 63.07 & 63.07 & 59.18 \\
\hline
\end{tabular}

Bmax = maximum binding capacity $(\mathrm{U} / \mathrm{L}), K d=$ dissociation constant $(\mathrm{mg} / \mathrm{dL}), K m=$ Michaelis-Menten's constant $(\mathrm{mg} / \mathrm{dL})$ and $V m a x=$ maximum velocity $(\mathrm{U} / \mathrm{L})$ 
Table 7 Dose-response characteristics of the influence of Annona muricata ethyl acetate extracts on a-glucosidase activity

\begin{tabular}{|c|c|c|c|c|c|c|c|c|c|c|}
\hline & \multicolumn{2}{|c|}{$\begin{array}{l}\text { Dose-Response } \\
\text { characteristics }\end{array}$} & \multicolumn{2}{|c|}{$\begin{array}{l}\text { Sigmoid plot interpolation } \\
\text { characteristics }\end{array}$} & \multicolumn{2}{|c|}{$\begin{array}{l}\text { Hyperbola plot } \\
\text { interpolation } \\
\text { characteristics }\end{array}$} & \multicolumn{2}{|c|}{$\begin{array}{l}\text { Michaelis-Menten's } \\
\text { kinetics }\end{array}$} & \multicolumn{2}{|c|}{$\begin{array}{l}\text { Straight line regression } \\
\text { interpolation characteristics }\end{array}$} \\
\hline & LoglC50 & IC50 & $\overline{R^{2}}$ & Hill's slope & $B \max$ & $K d$ & $\mathrm{Km}$ & $V \max$ & Y-intercept & slope \\
\hline Fruit-pulp & 0.235 & 1.717 & 0.999 & 6.582 & 38.83 & -0.030 & $1.176 \times 10^{-16}$ & 41.59 & 41.67 & 44.23 \\
\hline Leaf & 0.283 & 1.919 & 0.999 & 7.390 & 51.49 & -0.063 & $1.825 \times 10^{-16}$ & 60.12 & 60.23 & 58.14 \\
\hline Stem-bark & 0.286 & 1.930 & 0.993 & 5.534 & 49.05 & -0.067 & $1.565 \times 10^{-16}$ & 57.93 & 57.93 & 55.96 \\
\hline Root-bark & 0.336 & 2.168 & 0.951 & 5.089 & 37.76 & -0.030 & $1.759 \times 10^{-16}$ & 40.44 & 40.44 & 43.14 \\
\hline Acarbose & 0.236 & 1.722 & 1.000 & 1.481 & 51.17 & -0.079 & $2.220 \times 10^{-16}$ & 63.07 & 63.07 & 59.18 \\
\hline
\end{tabular}

$B m a x=$ maximum binding capacity $(\mathrm{U} / \mathrm{L}), K d=$ dissociation constant $(\mathrm{mg} / \mathrm{dL}), K m=$ Michaelis-Menten's constant $(\mathrm{mg} / \mathrm{dL})$ and $V m a x=$ maximum velocity $(\mathrm{U} / \mathrm{L})$

potencies and abilities to delay the speed of the reactions catalyzed by the enzymes), while the Bmax described the possible efficacies of the extracts (i.e., the higher this property, the higher the efficacies and the abilities of the moieties involved the active sites of the enzymes to bind actively, firmly and efficiently to inhibit the speed of catalysis and hydrolysis of the carbohydrate substrate).

However, since these plant extracts (especially, the fruit-pulp extract) were observed to be effective in inhibiting $\alpha$-amylase and $\alpha$-glucosidase activities, which is one of the mechanisms involved in controlling postprandial glycemia, these extracts may be helpful in the management of obesity and diabetes.

\section{In vitro investigations}

One of the major strategies used in the treatment and management of diabetes which has been proven to be most effective is to decrease post-prandial hyperglycemia, at the intestinal-blood interphase, by targeting the point of carbohydrate hydrolysis and mobilization into the blood. The biochemical argument is that, if this point can be effectively checked, then the major underlying cause of diabetes ab initio (hyperglycemia) can be prevented. This can be achieved by using inhibitors such as acarbose, miglitol, and voglibose [4].

However, severe gastrointestinal side effects such as abdominal pain, flatulence, and diarrhea seen in the patients $[11,12]$ have been linked to the use of these drugs. These side effects can be explained due to the fermentation of undigested carbohydrates by resident bacteria in the colon which they are able to reach as a result of the complete inhibition of $\alpha$-amylase [4]. In addition, it is thought that some of these drugs may increase the incidence of renal tumors, hepatic injuries, acute hepatitis and pancreatitis [19].

Therefore, there is a need to identify and explore the amylase inhibitors from natural sources having fewer side effects.

Several studies have revealed that $\alpha$-amylase and $\alpha$ glucosidase activity have a great influence on blood glucose level and their inhibition could significantly decrease the postprandial rise in blood glucose [20]. Several inhibitors of $\alpha$-amylase and $\alpha$-glucosidase have been isolated from medicinal plants to serve as an alternative drug with increased potency and lesser adverse effects than existing synthetic drugs [21, 22]. $\alpha$-amylase inhibitory activity has been demonstrated in a number of plant extracts including Hibiscus sabdariffa L. (Malvaceae) [23], Artocarpus heterophyllus Lam. (Moraceae) [24], Amaranthus hypochondriacus L. (Amaranthaceae) [25], Punica granatum L. (Punicaceae), Mangifera indica L. (Anacardiaceae) [6], Arecae seeds (Palmaceae) and Corni fruits (Cornaceae) [26].

The obtained results of the In vitro $\alpha$-amylase inhibitory potential of methanolic, ethyl acetate and dichloromethane

Table 8 Dose-response characteristics of the influence of Annona muricata dichloromethane extracts on a-glucosidase activity

\begin{tabular}{|c|c|c|c|c|c|c|c|c|c|c|}
\hline & \multicolumn{2}{|c|}{$\begin{array}{l}\text { Dose-Response } \\
\text { characteristics }\end{array}$} & \multicolumn{2}{|c|}{$\begin{array}{l}\text { Sigmoid plot interpolation } \\
\text { characteristics }\end{array}$} & \multicolumn{2}{|c|}{$\begin{array}{l}\text { Hyperbola plot } \\
\text { interpolation } \\
\text { characteristics }\end{array}$} & \multicolumn{2}{|c|}{$\begin{array}{l}\text { Michaelis-Menten's } \\
\text { kinetics }\end{array}$} & \multicolumn{2}{|c|}{$\begin{array}{l}\text { Straight line regression } \\
\text { interpolation characteristics }\end{array}$} \\
\hline & LoglC50 & IC50 & $\overline{R^{2}}$ & Hill's slope & $B$ max & $K d$ & $\overline{K m}$ & $V \max$ & Y-intercept & slope \\
\hline Fruit-pulp & 1.445 & 27.86 & - & 1.068 & 46.18 & -0.068 & $1.486 \times 10^{-16}$ & 54.79 & 54.89 & 53.00 \\
\hline Leaf & 0.857 & 7.188 & - & 1.325 & 47.43 & -0.061 & $2.000 \times 10^{-16}$ & 55.05 & 55.15 & 53.74 \\
\hline Stem-bark & 1.253 & 17.91 & - & 1.144 & 46.69 & -0.065 & $1.878 \times 10^{-16}$ & 54.79 & 54.88 & 53.25 \\
\hline Root-bark & 0.629 & 4.254 & 1.000 & 1.375 & 48.50 & -0.065 & $1.642 \times 10^{-16}$ & 57.02 & 57.12 & 55.15 \\
\hline Acarbose & 0.236 & 1.722 & 1.000 & 1.481 & 51.17 & -0.079 & $2.220 \times 10^{-16}$ & 63.07 & 63.07 & 59.18 \\
\hline
\end{tabular}




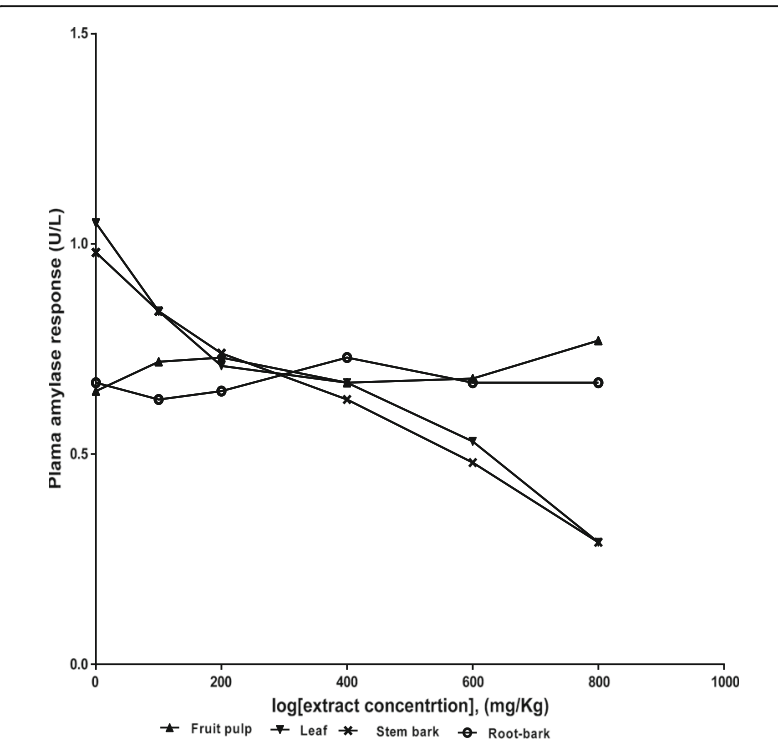

Fig. 1 Dose-response line plot of the influence of Annona muricata methanolic extract on plasma amylase activity

extracts of the fruit-pulp, leaf, stem-bark, and root-bark of A. muricata is shown in Figs. 3, 4, 5, 6, 7 and 8. For methanolic extract, the stem-bark (IC50 $=1.843 \mathrm{mg} / \mathrm{dL}$ ) showed the highest inhibitory effect followed by leaf extract, then fruit-pulp and root-bark with IC50 of $1.846 \mathrm{mg} / \mathrm{dL}, 2.163$ $\mathrm{mg} / \mathrm{dL}$ and $2.177 \mathrm{mg} / \mathrm{dL}$, respectively, compared to Acarbose $(1.722 \mathrm{mg} / \mathrm{dL})$. At the highest concentration of 3.20 $\mathrm{mg} / \mathrm{dL}$, the methanol extract of fruit-pulp, leaf, stem-bark and root-bark showed a $63.46 \%$ and $77.49 \%, 79.22 \%$ and $67.33 \%$ inhibitory effect respectively on $\alpha$ - amylase activity as against the $91.51 \%$ shown by Acarbose. The high total

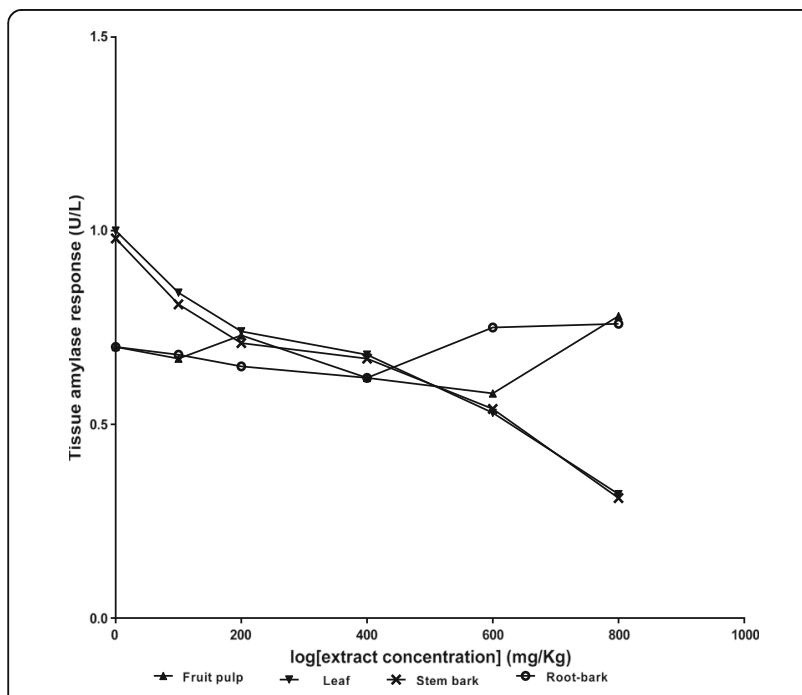

Fig. 2 Dose-response line plot of the influence of Annona muricata methanolic extract on tissue amylase activity

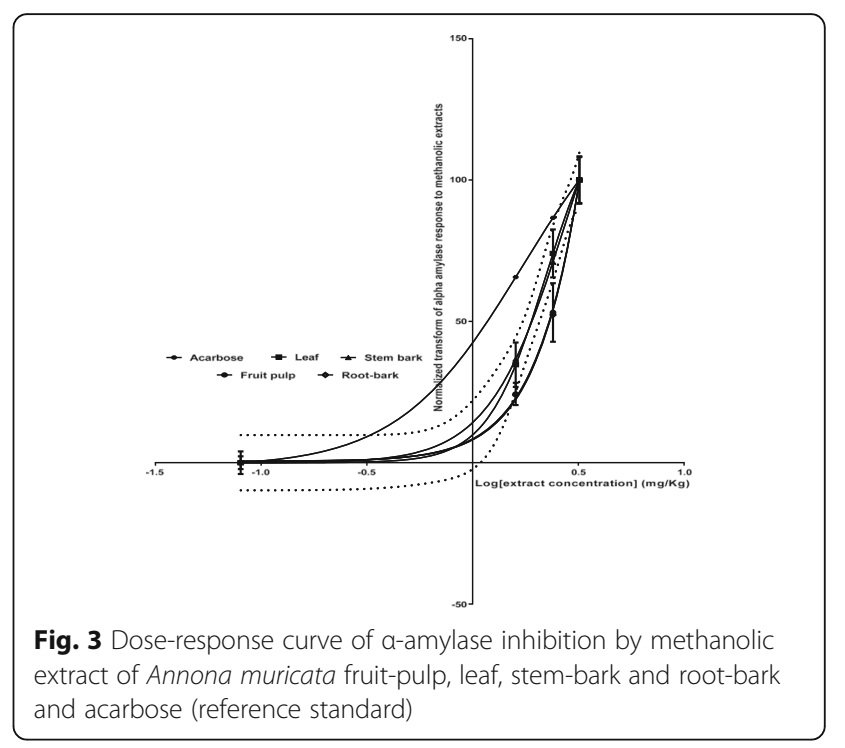

phenol content of the methanolic leaf and fruit-pulp extracts of A. muricata [7] may be responsible for this high inhibitory effect. This is consistent with earlier studies where $\alpha$-amylase and $\alpha$-glucosidase inhibitory effects of plant foods were attributed to their phenolic constituents [27-29]. The observed effects may also be due to the presence of more chemical constituents such as acetogenins, lignans (phyllanthin and hypophyllanthin), terpenes, flavonoids (quercetin, quercetin, rutin), and alkaloids in the methanolic extracts of the fruit-pulp and leaves. This observed higher inhibitory potencies of the leaf and stem-bark was corroborated by their higher Bmax and Vmax values (Table 3).

The result of the $\alpha$-amylase inhibitory activities of the ethyl acetate extracts of the fruit-pulp, leaf, stem-bark and root-bark showed that the fruit-pulp and root-bark extracts gave the higher inhibitory effect with IC50 of $2.196 \mathrm{mg} / \mathrm{dL}$ and $2.997 \mathrm{mg} / \mathrm{dL}$, respectively, compared with the standard Acarbose $(\mathrm{IC} 50=1.722 \mathrm{mg} / \mathrm{dL}$ ), and also the higher $K d$

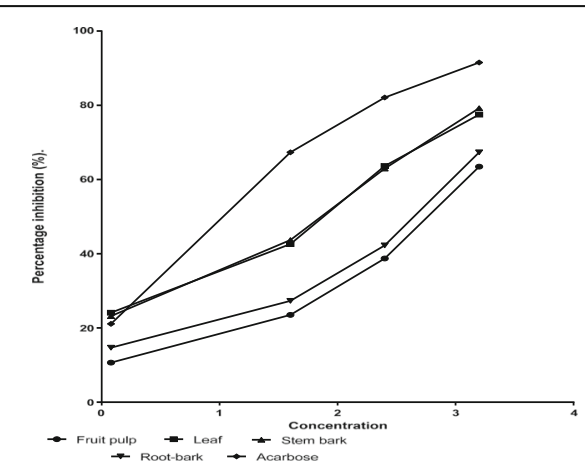

Fig. 4 Percentage inhibition of a-amylase by methanolic extract of Annona muricata fruit-pulp, leaf, stem-bark, root-bark and acarbose (reference standard) 


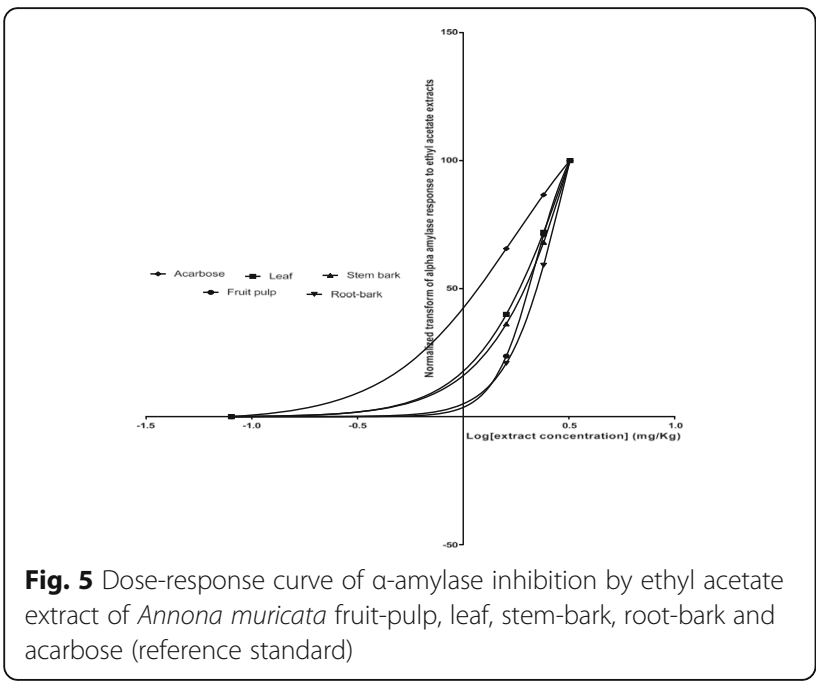

value compared with the leaf and stem-bark extracts with the higher Bmax and Vmax (Table 4). For the dichloromethane extracts (Table 5), the leaf and fruit-pulp extracts had the highest inhibitory effects (IC50 of $2.127 \mathrm{mg} / \mathrm{dL}$ and $2.761 \mathrm{mg} / \mathrm{dL}$, respectively; $K d$ of -0.044 and $-0.054 \mathrm{mg} / \mathrm{dL}$, respectively) as against that of Acarbose (IC50 of $1.722 \mathrm{mg} / \mathrm{dL} ; K d$ of -0.079 ).

The result of the $\alpha$-glucosidase inhibitory activity is demonstrated by Figs. 9, 10, 11, 12, 13 and 14. For the methanolic extracts, the leaf extract (IC50 of $1.623 \mathrm{mg}$ / $\mathrm{dL})$ showed the highest $\alpha$-glucosidase inhibitory effect; this was closely followed by the stem-bark, root-bark and lastly fruit-pulp (IC50 of $2.077 \mathrm{mg} / \mathrm{dL}, 6.483 \mathrm{mg} / \mathrm{dL}$ and $6.734 \mathrm{mg} / \mathrm{dL}$, respectively); this observed higher potency of the methanolic leaf extract against $\alpha$ glucosidase is strongly corroborated by the higher $B \max$ $(51.49 \mathrm{U} / \mathrm{L})$, lower $K d(-0.030 \mathrm{mg} / \mathrm{dL})$ and higher $V \max$ (60.12 U/L) compared to the other methanolic extracts and acarbose (Table 6). For the ethyl acetate extract, the fruit-pulp gave the highest inhibitory potency against $\alpha$ glucosidase activity compared to the leaf extract, then the stem-bark and root-bark; fruit-pulp had an IC50 of

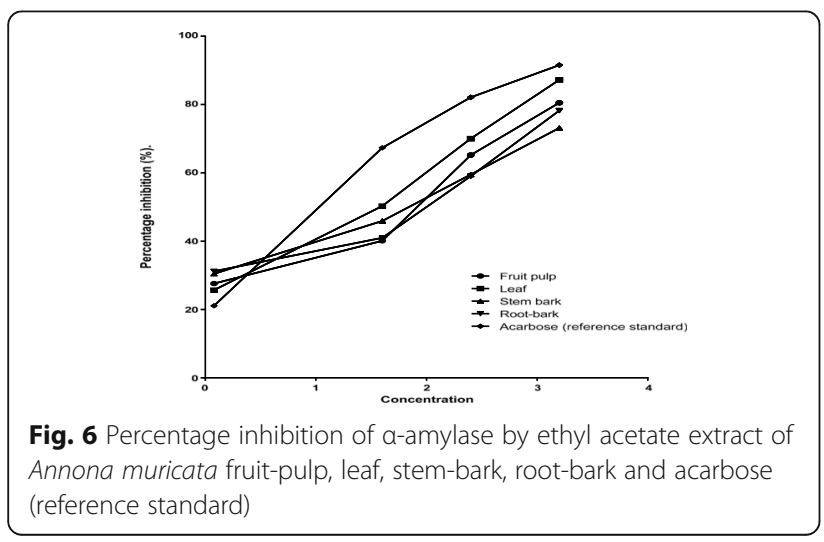

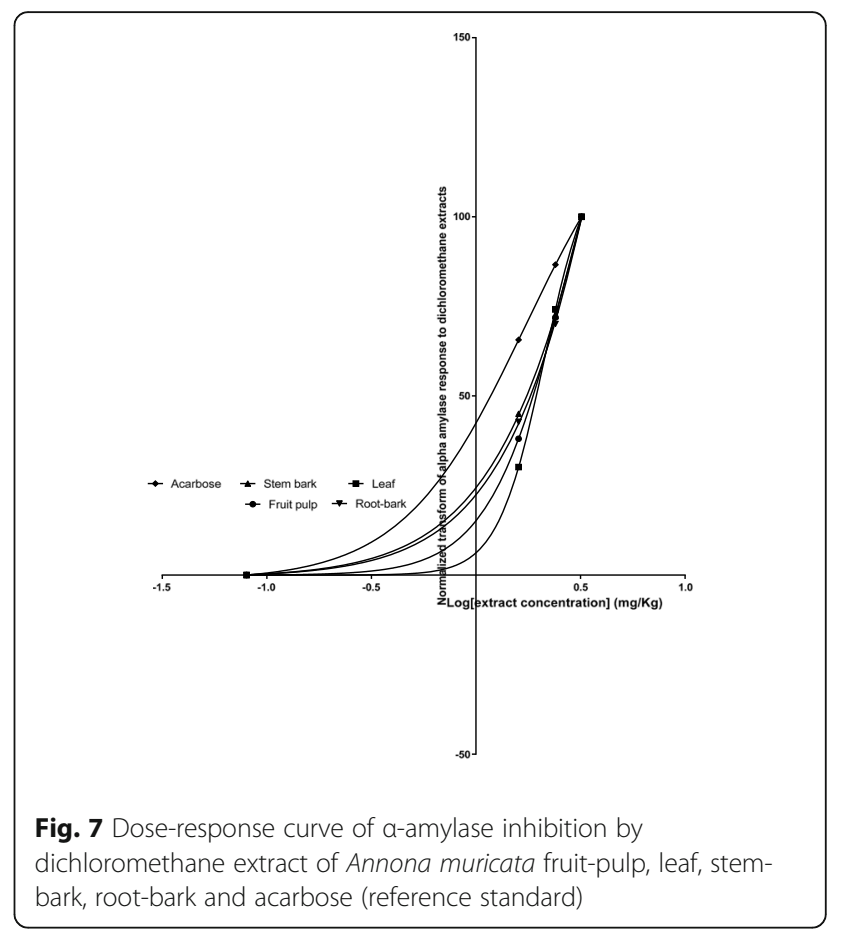

$1.717 \mathrm{mg} / \mathrm{dL}$ ( $K d$ of $-0.030 \mathrm{mg} / \mathrm{dL}$ ) better than acarbose with an IC50 of $1.722 \mathrm{mg} / \mathrm{dL}$ ( $K d$ of $-0.079 \mathrm{mg} / \mathrm{dL}$ ). However, the ethyl acetate leaf extract demonstrated a better efficacy with $B \max$ of $51.49 \mathrm{U} / \mathrm{L}$ and $V \max$ of 60.12 U/L, compared to acarbose with Bmax of $51.17 \mathrm{U} / \mathrm{L}$ and Vmax of $63.07 \mathrm{U} / \mathrm{L}$ (Table 7). For the dichloromethane extract, the root-bark gave the highest $\alpha$-glucosidase inhibitory effect (IC50 of $4.254 \mathrm{mg} / \mathrm{dL}$ ), closely followed by leaf extract, stem-bark and fruit-pulp with IC50 of $7.188 \mathrm{mg} / \mathrm{dL}$, $17.91 \mathrm{mg} / \mathrm{dL}$, and $27.86 \mathrm{mg} / \mathrm{dL}$, respectively (Table 8 ). The root-bark dichloromethane extract demonstrated the highest $B \max (48.50 \mathrm{U} / \mathrm{L})$ and $V \max (57.02 \mathrm{U} / \mathrm{L})$, compared to the other dichloromethane extracts. These results obtained for the extracts of the different parts of Annona muricata

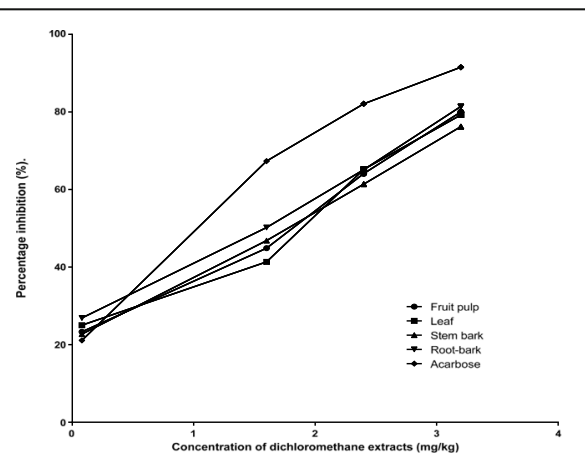

Fig. 8 Percentage inhibition of a-amylase by dichloromethane extract of Annona muricata fruit-pulp, leaf, stem-bark, root-bark and acarbose (reference standard) 


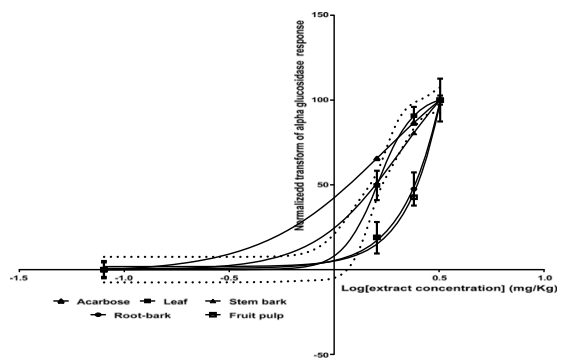

Fig. 9 Dose-response curve of a-glucosidase inhibition by methanolic extract of Annona muricata fruit-pulp, leaf, stem-bark, root-bark and acarbose (reference standard)

clearly shows that leaf and fruit-pulp exhibited a better inhibitory effect than the standard drug acarbose and therefore may be used as natural sources of management of post-prandial hyperglycemia. Also observed in this study was that the extracts exhibited a better $\alpha$-glucosidase inhibitory activity (potency and efficacy) compared to the $\alpha$ amylase activity. Earlier reports by Stephen et al. [30] on the distribution of phenolic contents, anti-diabetic potentials, anti-hypertensive properties, and anti-oxidative effects of Soursop (Annona muricata L.) fruit parts in vitro showed that Soursop extracts significantly inhibited $\alpha$ glucosidase more than $\alpha$-amylase. Kwon et al. [31] had earlier suggested that natural $\alpha$-glucosidase inhibitors from plants had been shown to have strong inhibitory activity against $\alpha$-glucosidase and therefore can be potentially used as an effective therapy for the management of postprandial hyperglycemia with minimal side effects.

To suggest or predict the nature of inhibition (competitive, non-competitive, uncompetitive, or mixed exhibited by the extracts) data are often analyzed by a set of techniques that linearize inherently non-linear relationships such as the Lineweaver-Burke's plot. We tried to understand the inhibition mechanism utilized against $\alpha$-amylase and $\alpha$-glucosidase by extracts of different parts of the Annona muricata. When compared

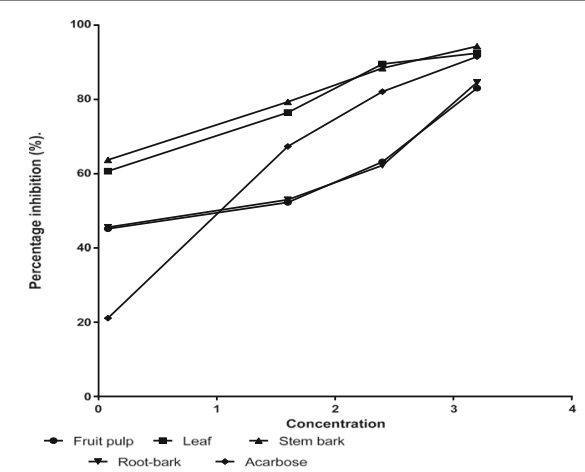

Fig. 10 Percentage inhibition of a-glucosidase by methanolic extract of Annona muricata fruit-pulp, leaf, stem-bark, root-bark and acarbose (reference standard)

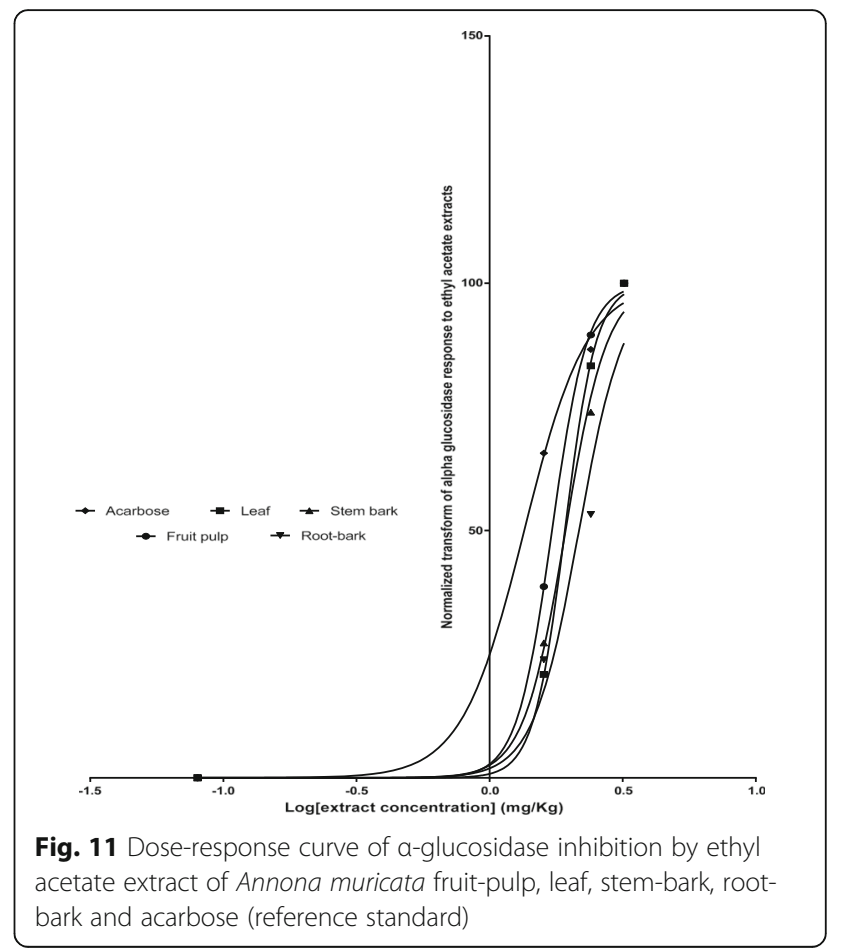

with the standard drug (acarbose), all the extracts showed decreases in $K m$ and Vmax, thus, suggesting that all extracts may have exhibited an uncompetitive inhibition pattern. This means that the active compound(s) in the extracts bind only to the enzymesubstrate complex (the inhibitor binding is only assessable when the carbohydrate binds to $\alpha$-amylase and $\alpha$ glucosidase) and that, the inhibition cannot be reversed by increase in the substrate concentration, i.e., intestinal carbohydrate; these confer a high level of benefits for

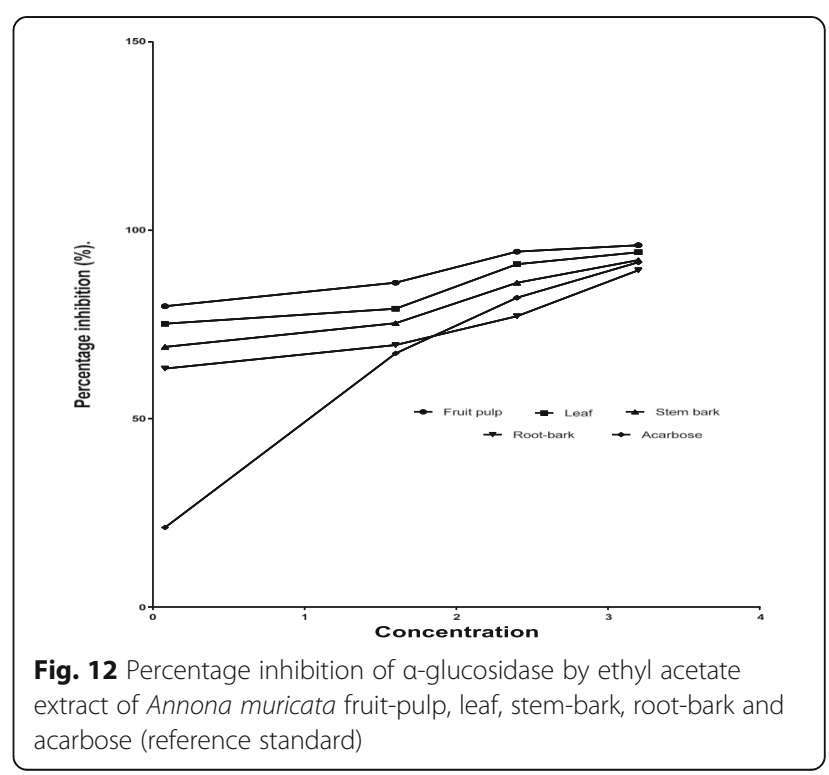




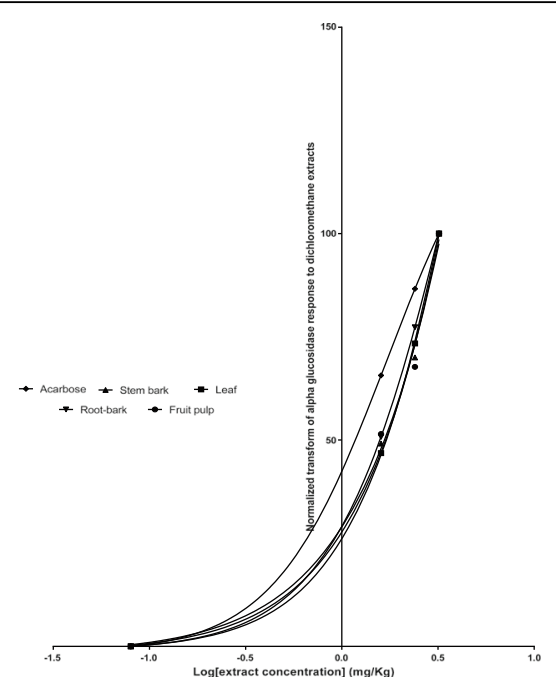

Fig. 13 Percentage inhibition of a-glucosidase by dichloromethane extracts of Annona muricata fruit-pulp, leaf, stem-bark, root-bark and acarbose (reference standard)

diabetics indicating that no matter the consumed concentration of carbohydrate, $\alpha$-amylase, and $\alpha$-glucosidase will be inhibited preventing or reducing glucose mobilization into the blood postprandial. Thus, to increase $\alpha$-amylase and $\alpha$-glucosidase affinity for carbohydrate, the enzyme-substrate complex must be decreased, but with the presence of the inhibitors present in Annona muricata, this becomes unachievable especially during the fed state of the diabetic; uncompetitive inhibition works best when the substrate concentration is high ("a light at the end of the tunnel for diabetics").

\section{In silico investigations}

In an attempt to narrow this observed potency and efficacy of the leaf and fruit-pulp extracts in uncompetitive

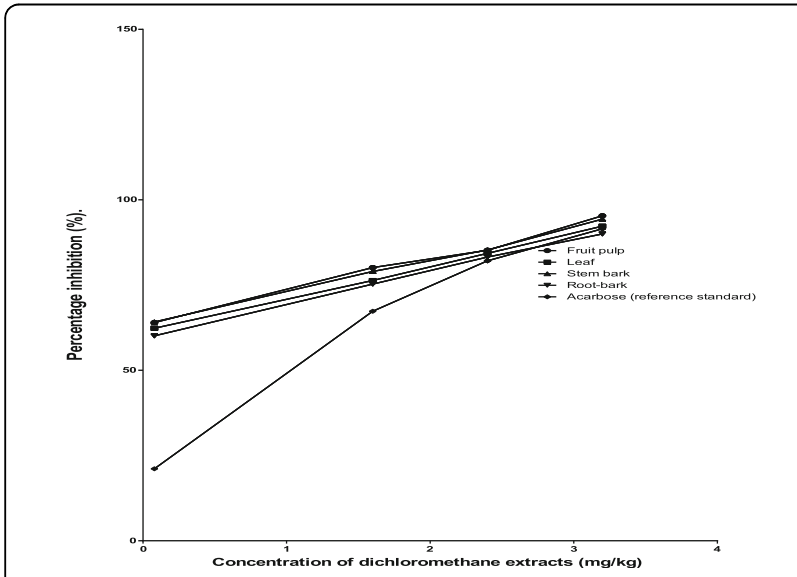

Fig. 14 Percentage inhibition of a-glucosidase by dichloromethane extract of Annona muricata fruit-pulp, leaf, stem-bark, root-bark and acarbose (reference standard) inhibition of $\alpha$-amylase and $\alpha$-glucosidase, an isolated acetogenin [8] identified as 15-acetyl guanacone was subjected to molecular docking experiments to ascertain its affinity levels of these enzymes compared to a standard, metformin (Figs. 15, 16, 17, 18 and 19).

The strong $\alpha$-amylase and $\alpha$-glucosidase inhibitory potentials observed in the ethyl acetate extracts of fruit (and leaf) may be linked to the presence of 15acetyl-guanacone (a compound isolated from the ethyl acetate fraction of fruit-pulp of Annona muricata) [8].

The molecular docking tool has been used to study the inter-relationship between a small molecule and a receptor at the atomic level, which may give the insight to characterize the behavior of small molecules in the binding site of target proteins, as well as to elucidate biochemical processes (amino acids bonded to an active site) [32]. The knowledge of the interaction between compounds and digestive enzymes may be an initial stage toward the synthesis of drug, nutraceuticals or functional foods [32].

It was observed that the binding of metformin (a standard drug) to the active site of $\alpha$-amylase and $\alpha$ glucosidase gave binding energies of $-4.90 \mathrm{kcal} / \mathrm{mole}$ $(\alpha$-amylase) and $-5.40 \mathrm{kcal} / \mathrm{mole}$ ( $\alpha$-glucosidase), while the binding of 15 -acetyl guanacone to the active site of $\alpha$-amylase and $\alpha$-glucosidase gave binding energies of $-6.80 \mathrm{kcal} / \mathrm{mole}$ and $-7.00 \mathrm{kcal} / \mathrm{mole}$, respectively. Thus the isolated compound demonstrated a better ability to bind to the enzymes than the standard drug, metformin. These observations corroborate the observed significantly higher $B \max$ and $K d$ values observed for the fruit-pulp and leaf extracts.

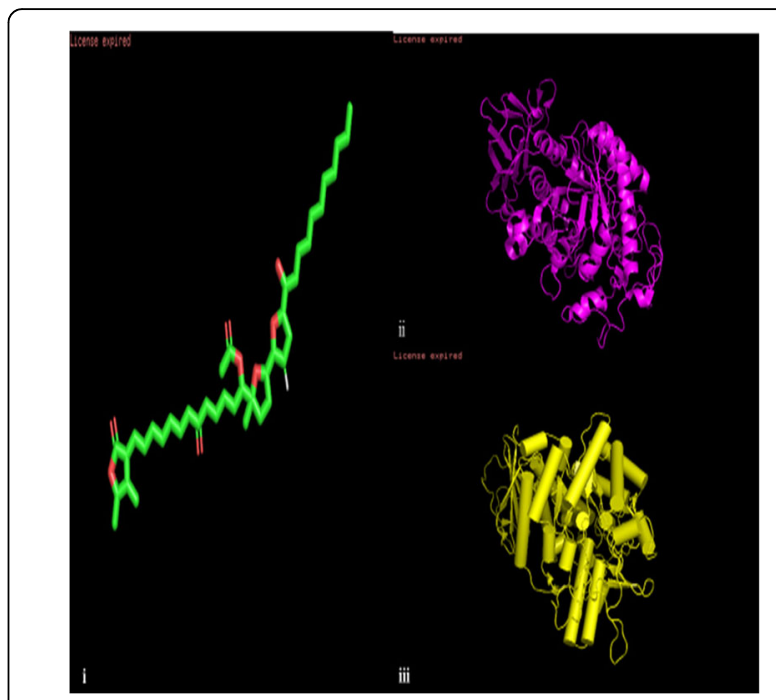

Fig. $152 \mathrm{D}$ structure of 15-acetyl guanacone (i), the 3D structure of a-amylase (ii), and 3D structure of a-glucosidase (iii) 


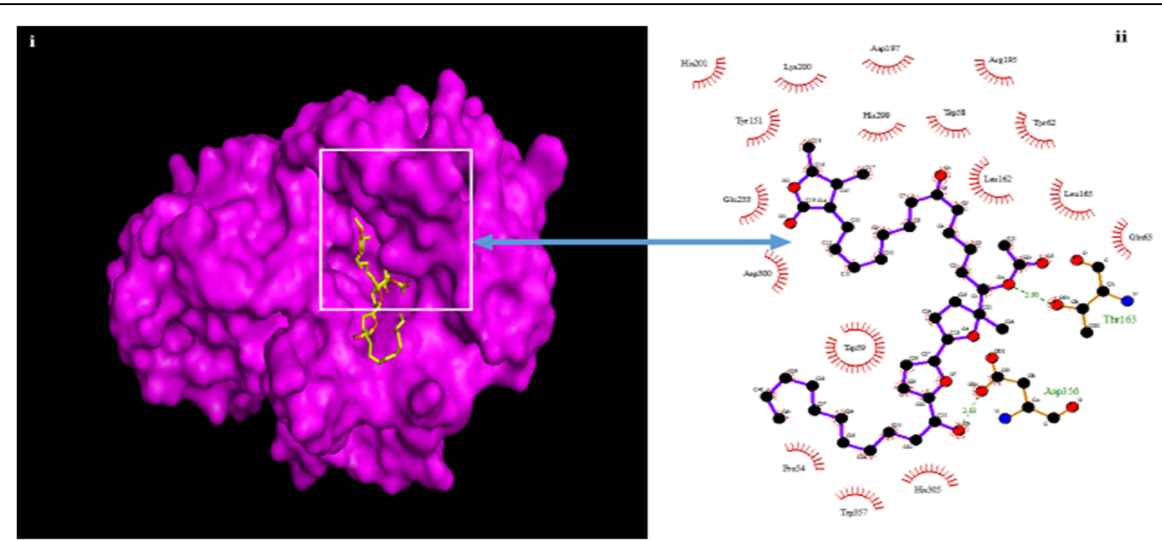

Fig. 16 The Binding pose of 15-acetyl guanacone at the active site of a-amylase with a binding energy of - $6.80 \mathrm{kcal} / \mathrm{mole}$ (i), and molecular interaction of 15-acetyl guanacone with amino acid residues within the active site of a-amylase (ii)

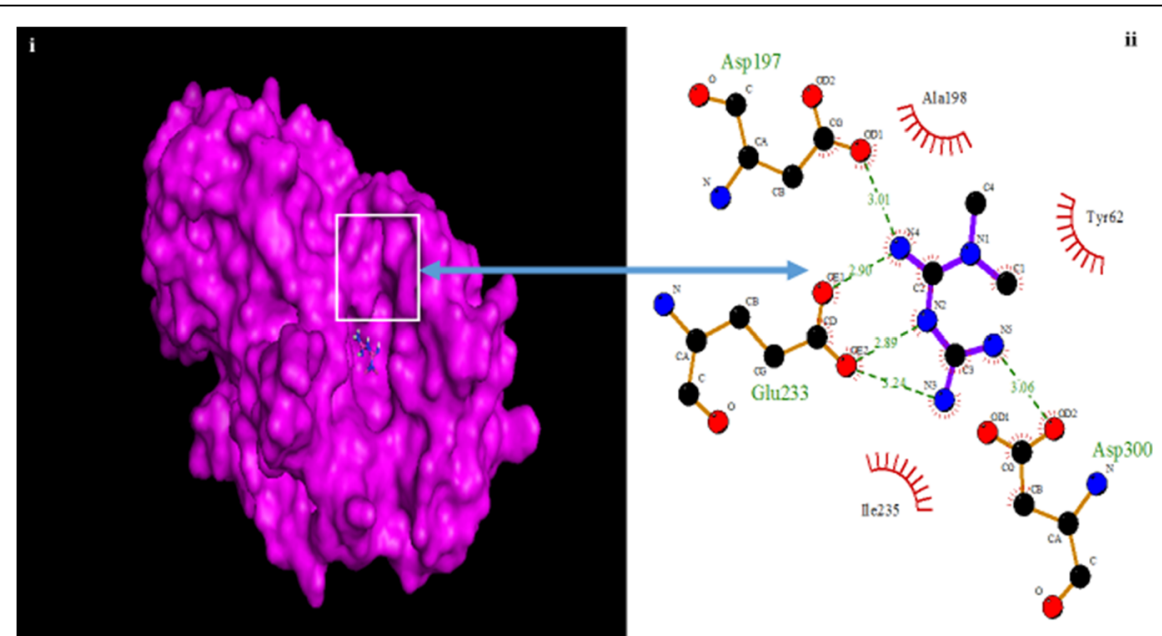

Fig. 17 The Binding pose of metformin at the active site of a-amylase with a binding energy of $-4.90 \mathrm{kcal} / \mathrm{mole}$ (i), and molecular interaction of metformin with amino acid residues within the active site of a-amylase (ii)
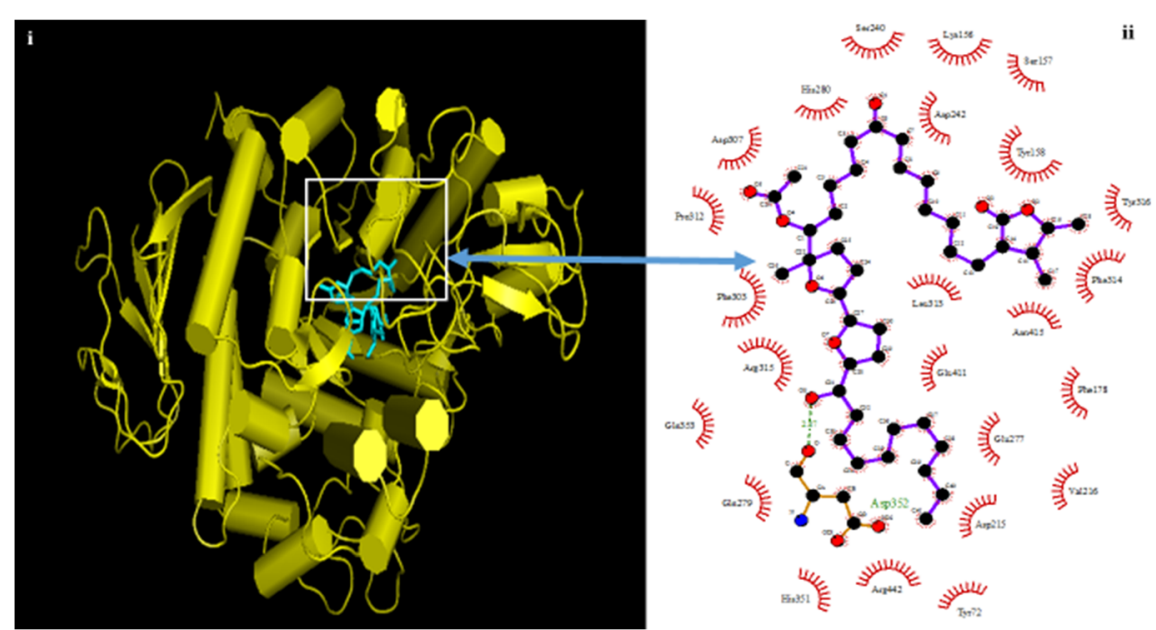

Fig. 18 The Binding pose of 15-acetyl guanacone at the active site of a-glucosidase with a binding energy of $-7.00 \mathrm{kcal} / \mathrm{mole}$ (i), and molecular interaction of 15-acetyl guanacone with amino acid residues within the active site of a-glucosidase (ii) 


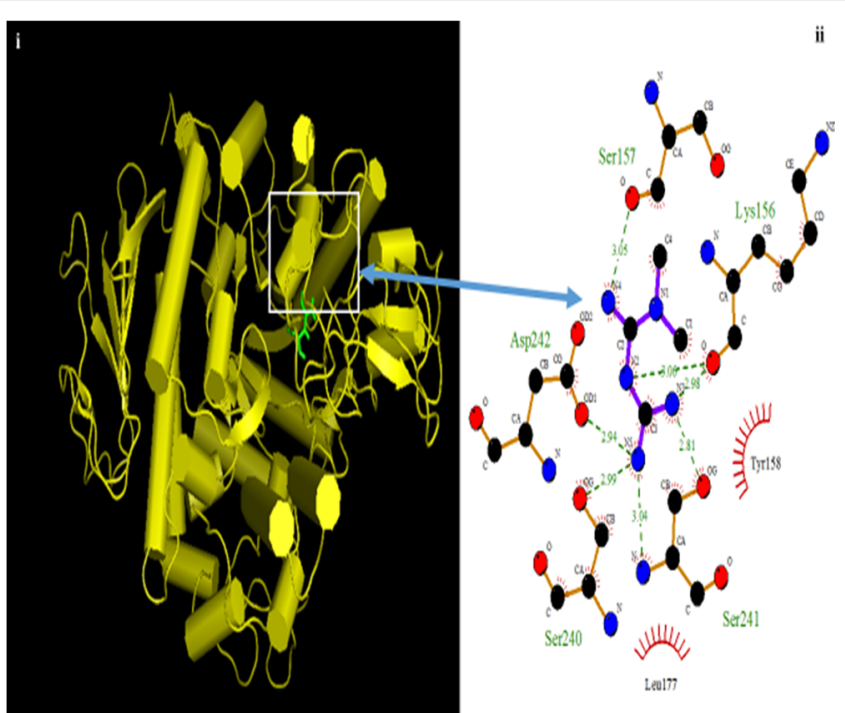

Fig. 19 The Binding pose of metformin at the active site of a-glucosidase with a binding energy of $-5.40 \mathrm{kcal} / \mathrm{mole}$ (i), and molecular interaction of metformin with amino acid residues within the active site of a-glucosidase (ii)

\section{Conclusion}

The fruit-pulp and leaf of Annona muricata (Soursop) demonstrated significantly high abilities to inhibit $\alpha$ amylase and $\alpha$-glucosidase and minimize the rate of glucose assimilation into the blood after feeding. This is evident in the obtained IC50, Bmax, Kd and Vmax values which further suggested that the mechanism of inhibition is that of uncompetitive inhibition, thus conferring an appreciable potency and efficacy for the plant compared to standard drugs. The research also suggested that these acetogenins may be responsible for these remarkable observations as was demonstrated by in silico studies using 15 -acetyl guanacone. Thus, Annona muricata can be very beneficial in the treatment and management of hyperglycemia, diabetes, overweight, and obesity, etc. This suggests that better natural remedies for diabetics can be obtained from Annona muricata with minimal or no adverse side effects.

\section{Acknowledgments}

We really appreciate the efforts of the Department of Medical Biochemistry, University of Benin, Nigeria, Mr. christopher Afo Ugbodaga and Dr. (Mrs.) Josephine Ofeimun.

\section{Authors' contributions}

KCA provided the funding and designed the research protocol, KCA and NE wrote the manuscript, ROO and DA assisted during the in vivo studies, Gl, MOO and $\mathrm{POO}$ assisted during the in vitro studies, while OOE assisted during the in silico studies. All authors read and approved the final manuscript.

\section{Funding}

The research was privately funded by KCA.
Ethics approval and consent to participate

Written approval of the research ethics committee guideline principles on the handling of animals of the College of Medicine, University of Benin (CMR/REC/2014/57) was adopted and strictly adhered to.

\section{Consent for publication}

All the authors participated in developing the manuscript and grant their consent for onward publication.

\section{Competing interests}

All the authors declare no competing interests.

\section{Author details}

'Department of Medical Biochemistry, School of Basic Medical Sciences, University of Benin, Benin City, Edo State 300001, Nigeria. ${ }^{2}$ Department of Science Laboratory Technology, Faculty of Life Sciences, University of Benin, Benin City, Edo State 300001, Nigeria. ${ }^{3}$ Department of Biochemistry, Adekunle Ajasin University, Ondo, Nigeria.

Received: 25 January 2019 Accepted: 29 May 2019

Published online: 13 June 2019

\section{References}

1. Aguiree F, Brown A, Cho NH et al...IDF Diabetes Atlas, 2013.

2. Mitra A. Preparation and effects of cheap salad oil in the Management of Type 2 rural Indian diabetics. J Hum Ecol. 2008:23:27-38.

3. Mitra A. Some salient points in dietary and lifestyle survey of rural Bengal particularly tribal populace in relation to rural diabetes prevalence. Studies on Ethnomedicine. 2008;2(1):51-6.

4. Bischoff H, Puls W, Krause HP, Schutt H, Thomas G. Pharmacological properties of the novel glucosidase inhibitors BAY m 1099 (miglitol) and BAY o 1248. Diabetes Res Clin Pract. 1985;1:53-62.

5. Valiathan MS. Healing plants. Curr Sci. 1998;75(11):1122-7.

6. Prashanth D, Padmaja R, Samiulla DS. Effects of certain plant extracts on aamylase activity. Fitoterapia. 2001;72:179-81.

7. Agu KC, Okolie NP, Eze Gl, Anionye JC, Falodun A. Phytochemical analysis, toxicity profile and hemo-modulatory properties of Annona muricata (soursop). Egyptian Journal of Haematology. 2017;42:36-44.

8. Agu KC, Okolie NP, Falodun A, Erharuyi O, Igbe I, Elekofehinti OO, Oghagbon SE. Isolation and molecular docking experiments of 15acetylguanacone from Annona muricata Linn. J Appl Sci Environ Manag. 2017;21(2):236-43 
9. Okolie NP, Agu KC, Eze Gl. Protective effect of ethanolic leaf extract of Annona muricata Linn on some early events in Cycas-induced colorectal carcinogenesis in rats. Journal of Pharmaceutical Science and Innovation. 2013;2(4):14-21.

10. Okwu DE, Omodamiro OD. Effects of hexane extract and phytochemical content of Xylopia aethiopica and Ocimum gratissimum on the uterus of Guinea pig. Bio-Research. 2005;3(2):40-4

11. Abirami G, Nagarani Siddhuraju P. In vitro antioxidant, anti-diabetic, cholinesterase and tyrosinase inhibitory potential of fresh juice from Citrus hystrix and C. maxima fruits. Food Sci Human Wellness. 2014;3(1):16-25.

12. Huang THW, Peng G, Kota BP, et al. Anti-diabetic action of Punica granatum flower extract: activation of PPAR- $y$ and identification of an active component. Toxicol Appl Pharmacol. 2005;207(2):160-9.

13. Wallenfels $K$, Foldi $P$, Niermann $H$, Bender $H$, Linder D. The enzymatic synthesis, by transglucosylation of a homologous series of glycosidically substituted maltooligosaccharides and their use as amylase substrates. Carbohydr Res. 1978;61:359.

14. Worthington V., 1993. Alpha-amylase. In Worthington Enzyme Manual: Worthington Biochemical Corp. Freehold, NJ., pp. 36-41.

15. Worthington V., 1993. Maltose-a-glucosidase. In Worthington Enzyme Manual: Worthington Biochemical Corp. Freehold, NJ., pp. 261.

16. Oboh G, Ademiluyi AO, Akinyemi AJ, Henle T, Saliu JA, Schwarzenbolz U. Inhibitory effect of polyphenol-rich extracts of jute leaf (Corchorus olitorius) on key enzyme linked to type 2 diabetes (a-amylase and a-glucosidase) and hypertension (angiotensin I converting) in vitro. J Funct Foods. 2012;4(2): 450-8 https://doi.org/10.1016/j.jf.2012.02.003.

17. Gavanji S, Larki B, Mortazaeinezhad F. Bioinformatic prediction of interaction between flavonoids of propolis of honey bee and envelope glycoprotein GP120. International Journal of Scientific Research in Environmental Sciences. 2014;2:85-93.

18. Jia W, Gao W, Tang L. Antidiabetic herbal drugs officially approved in China. Phytother Res. 2003;17(10):1127-34.

19. Shobana S, Sreerama YN, Malleshi NG. Composition and enzyme inhibitory properties of finger millet (Eleusine coracana L.) seed coat phenolics: mode of inhibition of--glucosidase and pancreatic amylase. Food Chem. 2009; 115(4):1268-73.

20. Nair SS, Kavrekar V, Mishra A. In vitro studies on a-amylase and a glucosidase inhibitory activities of selected plant extracts. European Journal of Experimental Biology. 2013;3(1):128-32.

21. Matsui T, Ogunwande IA, Abesundara KJM, Matsumoto K. Antihyperglycemic potential of natural products. Mini-Rev Med Chem. 2006;6(3): 349-56.

22. Matsuda H, Morikawa T, Yoshikawa M. Antidiabetogenic constituents from several natural medicines. Pure Appl Chem. 2002;74(7):1301-8.

23. Hansawasdi C, Kawabata J, Kasai T. a -amylase inhibitors from roselle (Hibiscus sabdariffa Linn.) tea. Biosci Biotechnol Biochem. 2000;64:1041-3.

24. Kotowaroo MI, Mahomoodally MF, Gurib-Fakim A, Subratty AH. Screening of traditional antidiabetic medicinal plants of Mauritius for possible a -amylase inhibitory effects in vitro. Phytother Res. 2006;20:228-31.

25. Martins JC, Enassar M, Willem R, Wieruzeski JM, Lippens G, Wodak SJ. Solution structure of the main a -amylase inhibitor from amaranth seeds. Eur J Biochem. 2001;268:2379-89.

26. Choi HJ, Kim NJ, Kim DH. Inhibitory effects of crude drugs on a -glucosidase. Arch Pharm Res. 2000;23:261-6.

27. Saravanan S, Parimelazhagan T. In vitro antioxidant, antimicrobial and antidiabetic properties of polyphenols of Passiflora ligularis Juss, fruit-pulp. Food Sci Human Wellness. 2014;3(2):56-64.

28. Adefegha SA, Oboh G. Inhibition of key enzymes linked to type 2 diabetes and sodium nitroprusside-induced lipid peroxidation in rat pancreas by water extractable phytochemicals from some tropical spices. Pharm Biol. 2012;50(7):857-65.

29. Ademiluyi AO, Oboh G, Aragbaiye FP, et al. Antioxidant properties and In vitro a-amylase and a-glucosidase inhibitory properties of phenolics constituents from different varieties of Corchorus spp. Journal of Taibah University Medical Sciences. 2015;10(3):278-87.

30. Stephen AA, Sunday 1O, Ganiyu O. Distribution of phenolic contents, antidiabetic potentials, antihypertensive properties and antioxidative effects of soursop (Annona muricata L.) fruit parts In vitro. Biochem Res Int. 2015; 2015:347673.
31. Kwon Yl, Apostolidis E, Shetty K. Evaluation of pepper (Capsicum annuum) for management of diabetes and hypertension. J Food Biochem. 2007;31(3): 370-85.

32. McConkey BJ, Sobolev V, Edelman M. The performance of current methods in ligand-protein docking. Curr Sci. 2002;83:845-56.

\section{Publisher's Note}

Springer Nature remains neutral with regard to jurisdictional claims in published maps and institutional affiliations.

\section{Submit your manuscript to a SpringerOpen ${ }^{\circ}$ journal and benefit from:}

- Convenient online submission

- Rigorous peer review

- Open access: articles freely available online

High visibility within the field

- Retaining the copyright to your article

Submit your next manuscript at $\boldsymbol{\nabla}$ springeropen.com 